\title{
Initial stages of two Neolithisation models in the Lower Volga basin
}

\author{
Aleksandr Vybornov \\ Samara State University of Social Sciences and Education, Samara, RU \\ vibornov_kin@mail.ru
}

\begin{abstract}
In this paper, two groups of ancient sites located in the Lower Volga River basin are analysed. The first group is linked to the emergence of the oldest pottery in this region, which is one of the most ancient in Europe. The presence of this feature of the 'Neolithic package' can be dated to the middle of the $7^{\text {th }}$ millenium BC. A production economy is a particular feature of the second group of sites, which can be dated to the end of the $\sigma^{\text {th }}$ millenium BC. This is one of the earliest pieces of evidence of the existence of domesticated species in Eastern Europe. These two groups of sites show the initial stages of two Neolithisation models in the Lower Volga basin.
\end{abstract}

IZVLEČEK - V članku analiziramo dve skupini najdišč na območju spodnjega dela reke Volge. Prva skupina je vezana na pojav najstareǰ̌e lončenine na tem prostoru, ki je hkrati ena najstarejših v Evropi. Navzočnost lončenine, ki je del $t$. $i$. 'neolitskega paketa', lahko datiramo $v$ sredino 7 . tisočletja pr. n. št. Pojav produktivnega gospodarstva je značilnost druge skupine najdišč, ki jih datiramo na konec 6. tisočletja pr. n. št. To je eden najstarejših dokazov o navzočnosti udomačenih vrst živali v Vzhodni Evropi. Obe skupini najdišč predstavljata začetne stopnje dveh različnih modelov neolitizacije na območju spodnje Volge.

KEY WORDS - Neolithic; Lower Volga; pottery; production economy

\section{Introduction}

The Lower Volga basin lies in a special geographical area (Fig. 1); it connects the northern areas of the forest-steppe/forest zones of the Volga basin and the area of the Don basin with southern areas of the Caucasus and Central Asia. Such a location promoted contacts and interaction between cultures in these regions. The steppe zone of the Volga basin played a particular role in the Neolithisation process, whereby various characteristics of southern cultures could have penetrated farther. The emergence of ceramic production and cattle breeding in the steppe zone from the Dnieper to the Volga River basin can be linked to the region of Western Asia (Kotova 2002; Yudin 2004).

The innovations of the Neolithic constitute a 'Neolithic package', which includes a distinct set of components (Özdoğan 2011). In addition, the issue of
Neolithisation has led to many discussions and questions (Budja 2013), including the reasons for, and mechanisms of, the transition to the Neolithic era, as well as regional diversity. Since the publications of V. Gordon Childe (1958), a production economy has been considered one of the most important features of the Neolithic. The existence of pottery in the form of storage containers is also related to the appearance of a producing economy. However, no evidences of agriculture or cattle-breeding has been found in the Volga, Don, and Kama basins that date to the Neolithic, a fact which at first sight can be explained by its chronological position. On the other hand, early cases of ceramics appearing in hunter-gatherer cultures are also known today (Kuzmin 2015; Craig 2016; Gibbs, Jordan 2016). The term 'ceramic revolution' was coined to denote the oldest pottery remains found in Eastern Europe (Mazurkevich et al. 
2006). New research on stone age sites located in the Lower Volga basin allowed us to take a new look at the issue of Neolithisation in this region.

\section{Materials and discussion}

Kugat IV and Kulagaisi are two of the earliest sites with pottery in the southern part of the Lower Volga basin (Northern Caspian) in the Astrakhan region. Based on the material from the Kairshak III site (Vybornov 2008), they are attributed to Kairshak early Neolithic types of site, commonly found in the northern Caspian area. This type of site existed from $6690 \mathrm{BC}$ to $5980 \mathrm{BC}$ (Tab. 1). At that time, blades and blade tools predominated in the stone industry. Geometric microliths - rhomboid and circular segments with a retouched convex edge - are well represented (Fig. 2). These artefacts are typical of the local Mesolithic in-

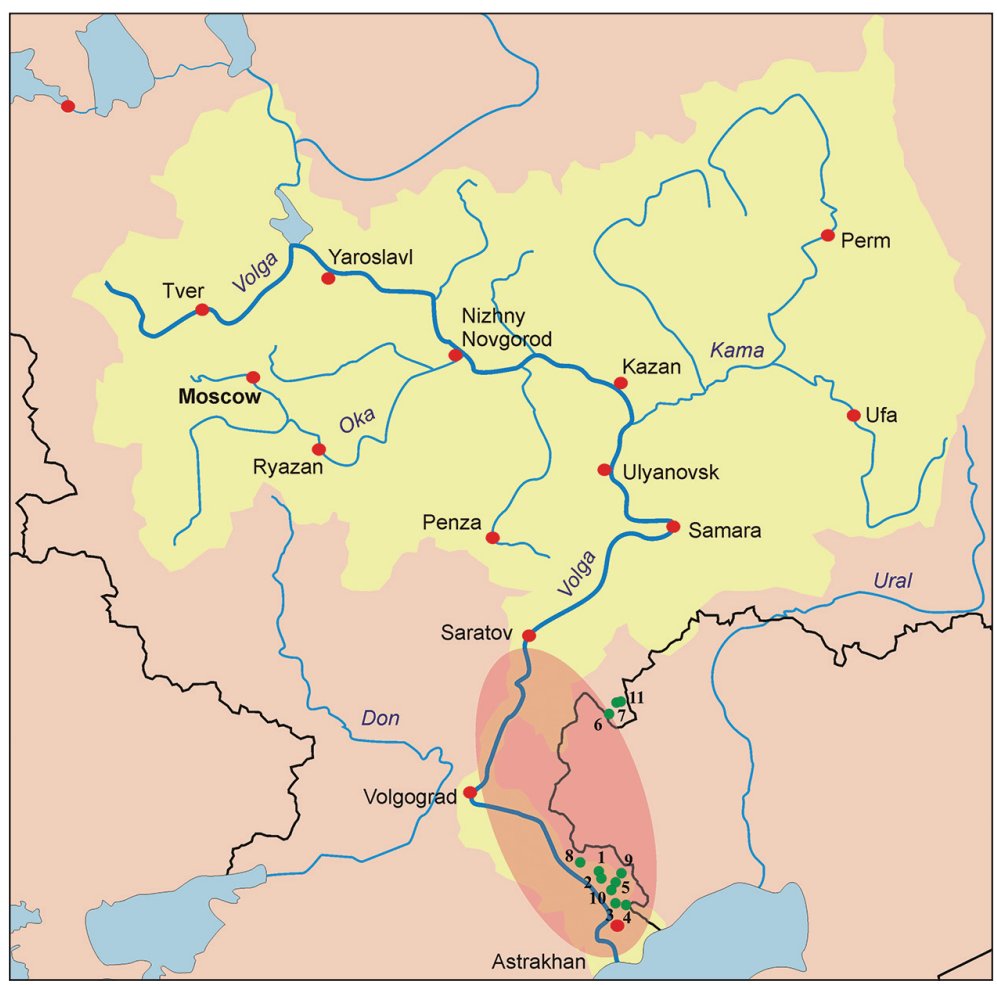

Fig. 1. Map of the Lower Volga region. 1 Kugat IV; 2 Kulagaysi; 3 Kairshak III; 4 Baibek; 5 Tenteksor; 6 Varfolomeevskaya; 7 Algay; 8 Karahuduk; 9 Kombakte; 10 Kurpezhe molla; 11 Oroshaemoe.

dustry (Vybornov et al. 2015). These testify to the local origin of pottery in this region. Pottery attributed to the Kairshak type was made from silt naturally tempered with the shells of freshwater molluscs. This ceramic technology is thought to be the most ancient in the Volga and Kama basins (Vybornov, Vasilieva 2013). The sites in this region are the most ancient of the Kairshak sites, and are radiocarbon dated to 6690 cal BC (Zaitsteva et al. 2009).

The climatic factors which influenced the transition from one period to another present a complicated picture (Budja 2007). Extensive aridisation is thought to have occurred between 6400 and $6300 \mathrm{BC}$ in the southern part of the Low Volga basin (Bolikhovskaja 1990). This is also verified, according to the ${ }^{14} \mathrm{C}$ dates, by the absence of inhabited settlements at this time. Thus, the beginning of Neolithisation and pottery making in the Lower Volga basin could not have been connected to natural factors. The situation changed after the aridisation ended (6200 BC), and the number of sites increased (Kairshak I-IV, Baibek). Settlements became long-term; living conditions and the economic system changed, and so a great number of household objects, dwellings, artefacts and faunal and fish remains from that time can be found (Grechkina et al. 2014). We can suppose that the initial inhabitants of Kairshak-type sites in this region were more nomadic than the inhabitants of subsequent periods.

With the exception of dogs (Vybornov et al. 2015), the faunal remains found on sites with pottery dated to 6500-5680 BC (Kairshak III, Baibek, Tenteksor, Zhekolgan) were all wild species: saiga, onager, tarpan, auroch, wild boar, wolf, and fox (Vybornov et al. 2015).

The Neolithisation process in the southern part of the Low Volga region during 6500-5500 BC did not include a producing economy. From the point of view of European researchers, sites of this period could be attributed only to the 'ceramic Mesolithic'. In the eastern European scientific world, pottery is regarded as a marker of the beginning of the Neolithic era (Oshibkina 1996), which is why these sites were classified as Neolithic.

In the northern part of the Lower (steppe) Volga basin, sites with the earliest pottery are attributed to the Orlovskaya culture. The most important material was found in the lowest layer (3) of the Varfolomeevskaya site (Yudin 2004) and the lowest layer of the Algai site (Vybornov, Yudin 2015), both of which are located in the Saratov region. The flint industry is represented by blades and blade tools, and 


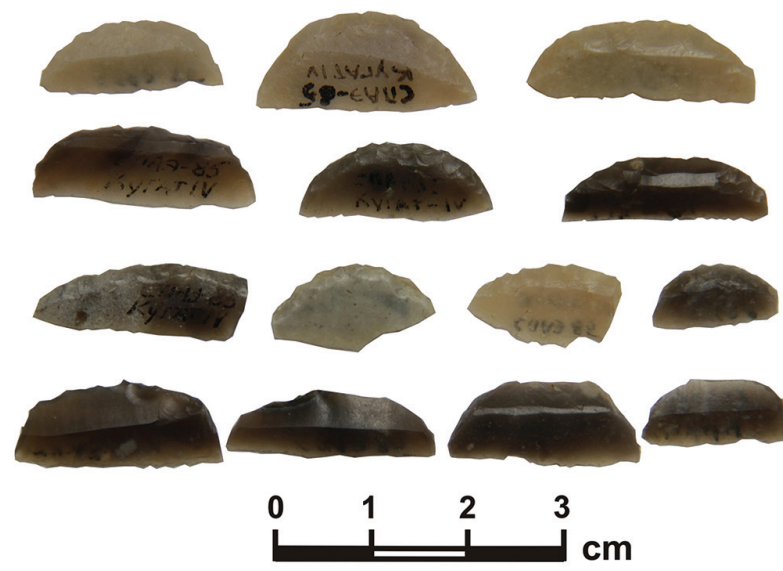

geometrical microliths - circular segments with a retouched arc. These features are typical of the stone industry of the Northern Caspian area. The flat-bottom ware of the Orlovskaya culture was made from silt and silty clay, naturally tempered with the shells of fresh-water molluscs - the same paste recipes as those used in the manufacture of Kairshak vessels. According to the ${ }^{14} \mathrm{C}$ dating, these materials date to 6200-6000 BC (Tab. 1), i.e. a period of a wider distribution of sites in the southern part of the Low Volga region. This allows us to suppose that the Neolithisation process in the steppe Volga basin was influenced by bearers of the Kairshak cultural tradition from the Northern Caspian area. The faunal remains in the steppe Volga (sites Varfolomeevskaya, Algai) during this time included saiga, onager, tarpan, auroch, wild boar, wolf, and fox. No evidence of a producing economy has been found at sites in the steppe Volga basin (Yudin 2004) or in the North-Western Caspian region (Koltsov 2004). Apart from dog, no traces of domesticated species have been found at Neolithic sites in this region (Vybornov et al. 2015). Thus, the Neolithisation model in the southern part of the Low Volga region during 6200-5500 (later than the beginning of Neolithisation in the Northern Caspian) was not connected with a producing economy. This process was not established locally. Neolithic culture was formed in the steppe Volga basin under the influence and by the interaction of some groups of Kairshak inhabitants from the Northern Caspian area with the local Mesolithic population.

Until recently, the appearance of a producing economy in the Low Volga was connected with Khvalynskaya culture sites (Karahuduk, Kairshak VI, Kombakte), which are dis-

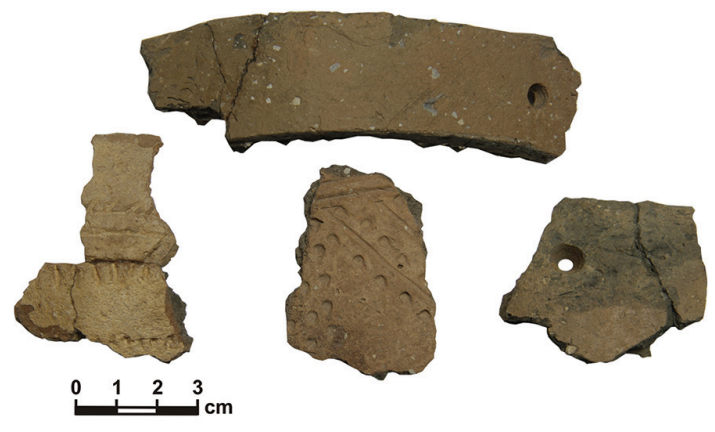

Fig. 2. Geometric microliths and pottery from $\mathrm{Ku}$ gan $I V$.

tributed throughout the whole of the steppe zone. The lithic industry of this culture differs from the flint industry of preceding cultures, as it includes heavy flakes produced by enhanced pressure knapping. Scrapers, knives, points on large blades, and triangular arrowheads with a truncated base predominated. There are also insets on narrow blades. Pottery was made from clay tempered with crushed freshwater mollusk shells. The upper part of the round-bottom vessels is thickened (Fig. 3). The deco-
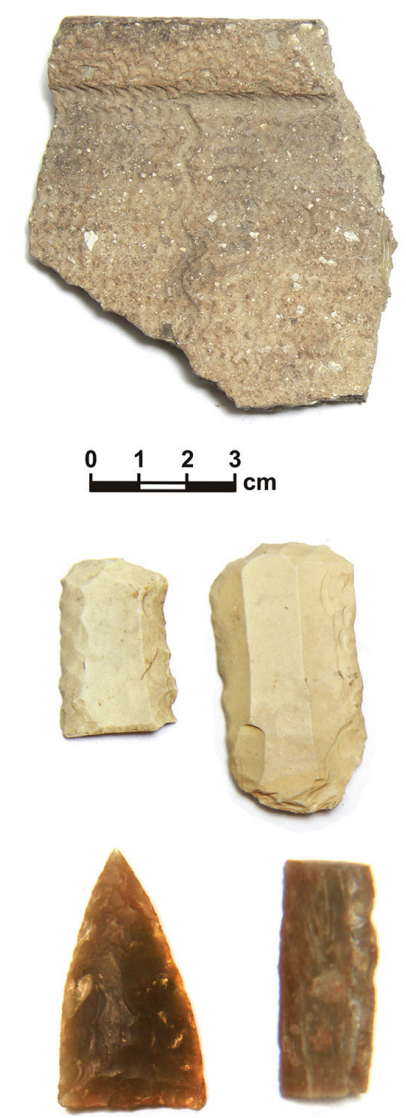

$\begin{array}{llll}0 & 1 & 2 & 3\end{array}$
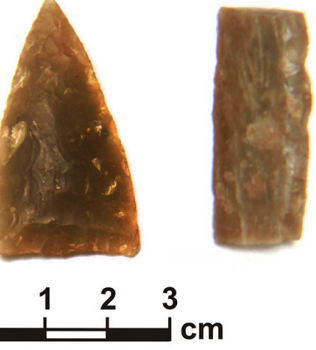

cm
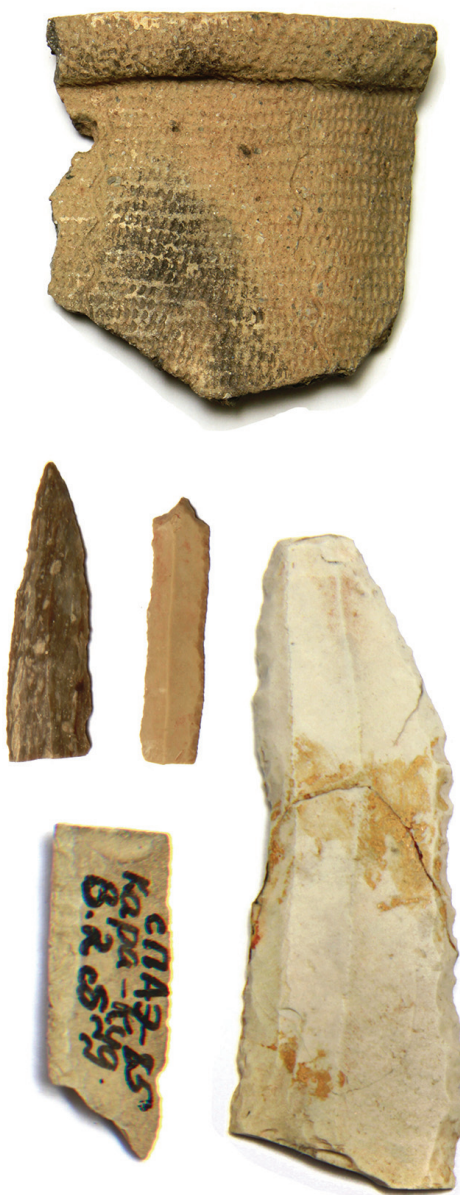

Fig. 3. Pottery and flint tools of the Khvalynsk culture. 
ration and technique of applying it to vessels differs from that found in the preceding Kairshak and Orlovskaya cultures (Vasiliev 2003). Domesticated sheep bones were found at Khvalynskaya sites, along with the bones of wild species (kulan, saiga, tarpan). Detailed statistical data can be found in a number of publications (Kuzmina 1988; Vybornov et al. 2015). Khvalynskaya culture sites date to $4900-4600$ BC (Tab. 1). There are two hypotheses about the origin of this culture. It has been suggested that it was an autochthonous culture formed on the basis of the preceding Prikaspiiskaya culture. Other researchers suppose that it could have appeared as the result of the migration of tribes from the southern region of the Trans-Caspian area.

It must be mentioned that the earliest copper ornaments were found in Khvalynskaya burials. This is why the culture could not have been involved in the Neolithisation process.

Remains of domesticated animals were also recently found at Prikaspiiskaya sites, preceding Khvalynskaya culture (Vybornov et al. 2015). It is located in the same area as Khvalynskaya culture. Evidence of a quarzite stone industry has been found at Prikaspiiskaya sites (Kurpezhe-molla and Oroshae-
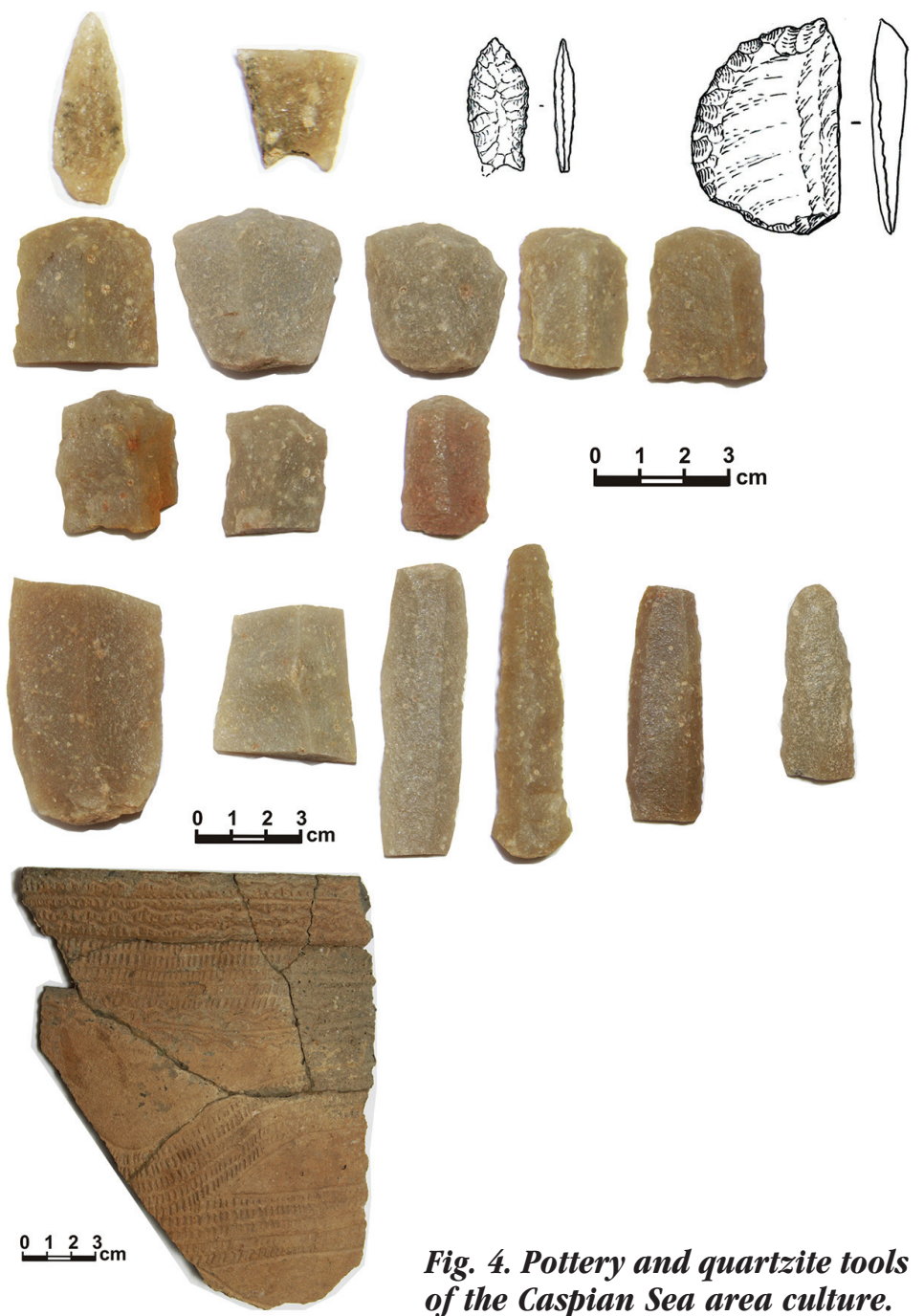

Fig. 4. Pottery and quartzite tools of the Caspian Sea area culture.

moe). Heavy flakes were used as preforms for tools produced by an enhanced pressure technique. Tools

\begin{tabular}{|lcccc|}
\hline Site & Age (BP) & Age, cal BC $(\mathbf{2 \sigma})$ & Material & Lab. No. \\
\hline Kugat IV & $7680 \pm 100$ & $6690-6380$ & Pottery carbon & Ki-14501 \\
\hline Kugat IV & $7560 \pm 90$ & $6600-6220$ & Pottery carbon & Ki-14500 \\
\hline Kulagaysi & $7380 \pm 120$ & $6450-6027$ & Pottery carbon & SPb-1725 \\
\hline Kairshak III & $7190 \pm 80$ & $6230-5890$ & Animal bone & Ki-14633 \\
\hline Baibek & $6986 \pm 44$ & $5983-5759$ & Charcoal & Ua-50260 \\
\hline Baibek & $6955 \pm 80$ & $6002-5708$ & Animal bone & SPb-973 \\
\hline Baibek & $6920 \pm 120$ & $6021-5624$ & Pottery carbon & SPb-1053 \\
\hline Tenteksor & $6695 \pm 40$ & $5680-5530$ & Ceramic food crust & Ua-35277 \\
\hline Varfolomeevskaya & $7230 \pm 90$ & $6250-5890$ & Pottery carbon & Ki-14368 \\
\hline Varfolomeevskaya & $7034 \pm 41$ & $6010-5830$ & Ceramic food crust & Ua-41360 \\
\hline Algay & $6800 \pm 40$ & $5741-5631$ & Ceramic food crust & Poz-65198 \\
\hline Algay & $6605 \pm 32$ & $5617-5487$ & Charcoal & AAR-21893 \\
\hline Karakhuduk & $5980 \pm 90$ & $4960-4770$ & Pottery carbon & Ki-14907 \\
\hline Kairshak VI & $5780 \pm 90$ & $4880-4600$ & Pottery carbon & Ki-14910 \\
\hline Burovaya 41 & $6790 \pm 80$ & $5840-5530$ & Pottery carbon & Ki-14618 \\
\hline Kurpezhe-Molla & $6020 \pm 80$ & $5150-4770$ & Pottery carbon & Ki-14832 \\
\hline Oroshaemoye & $5806 \pm 26$ & $4724-4557$ & Animal bone & UGAMS-23059 \\
\hline
\end{tabular}

Tab. 1. Radiocarbon dates for Neo-Eneolithic sites in the Lower Volga region. 
included scrapers, knives and points on large blades, 'fish-form' arrowheads, as well as insets on narrow flint blades. Flat-bottom pottery was made from clay artificially tempered with shells. The upper parts of the vessels have a thickened external side, called the 'neck-piece'. Pottery was decorated with comb impressions and traced lines (Fig. 4). All of these features are similar to the material from Khvalynskaya culture (Vasiliev 1981; Vybornov et al. 2015; 2016). Domesticated sheep bones were found alongside the bones of wild species (kulan, saiga, tarpan) ( $V y$ bornov et al. 2015). The Prikaspiiskaya sites are dated to 5500-4800 BC (Tab. 1). This culture is attributed to the Neolithic period, as no copper artefacts have been found. However, no traces of transition from the Kairshakskaya or Orlovskaya cultures to Prikaspiiskaya culture could be identified. The origin of Prikaspiiskaya culture is reckoned to be connected with the Lower Don region. Some migration from Western Asia could also have occurred. Thus, the Prikaspiiskaya sites in the Lower Volga region represent the second Neolithisation model proposed for this area. The model is connected with the appearance of a producing economy in the milieu of Prikaspiiskaya culture.

\section{Conclusion}

Two different Neolithisation models can be proposed for the Lower Volga region. The first could be dated to $6500 \mathrm{BC}$, and encompasses the appearance of the first sites with the oldest pottery, attributed to Kairshakskaya culture, in the Northern Caspian region. In the Lower Volga basin it could be dated to 6200 $\mathrm{BC}$, and is represented by Orlovskaya culture sites, which appeared under the influence of the southern groups of Kairshakskaya culture. The second Neolithisation model could be dated to 5500-4800 BC, and encompassed the whole area of the steppe Volga basin. It is connected to the incoming Prikaspiiskaya culture, which has yielded reliable traces of a producing economy.

Special thanks to Prof. M. Budja for the invitation to participate in Documenta Praehistorica with our article, project 33.1195.2014/K state order of the Russian Ministry of Education and Science and to RFBR for support with grant number 14-06-00041 (r).

\section{$\therefore$}

\section{References}

Bolikhovskaja I. S. 1990. Palinoindikacija izmenenija landshaftov Nizhnego Povolzh'ja v poslednie 10 tys. let. In L. I. Lebedeva, E. G. Maev (eds.), Kaspijskoe more. Voprosy geologii i geomorfologii. Nauka. Moscow: 52-68. (in Russian)

Budja M. 2007. The 8200 cal BP climate event and the process of neolithisathion in south-eastern Europe. Documenta Praehistorica 34: 191-201.

2013. Neolithic pots and potters in Europe the end of 'demic diffusion' migratory model. Documenta Praehistorica 40: 39-55.

Childe V. G. 1958. The Dawn of Europian Civilization. Knopf. New York.

Craig 0. E. 2016. The innovation and development of pottery in the Japanese archipelago. In O. V. Lozovskaya, A. N. Mazurkevich and E. V. Dolbunova (eds.), Tradicii $i$ innovacii v izuchenii drevneyshey keramiki. Institute for History of Material Culture Russian Academy of Science. St. Petersburg: 179-182.

Gibbs K., Jordan P. 2016. A comparative perspective on the 'western' and 'eastern' Neolithics of Eurasia: Cera- mics; agriculture and sedentism. Quaternary International 30: 1-9.

Grechkina T. Y., Vybornov A. A. and Kutukov D. V. 2014. Novaya ranneneoliticheskaya stoyanka Baybek v Severnom Prikaspii. Samarskiy nauchnyy vestnik 3: 79-90. (in Russian)

Koltsov P. M. 2004. Poseleniye Jangar. Izdatelstvo Novyi Hronograf. Moscow. (in Russian)

Kotova N. S. 2002. Neolithization of Ukraina. Izdatelstvo Shljach. Lugansk. (in Russian)

Kuzmin Y. 2015. The origins of pottery in East Asia (Updated analysis). Documenta Praehistorica 42: 1-11.

Kuzmina I. E. 1988. Mlekopitayushchie Severnogo Prikaspiya. In Arheologicheskie kultury Severnogo Prikaspiya. Kuybyshev: 173-188. (in Russian)

Mazurkevich A. N., Dolukhanov P. M., Shukurov A. M. and Zaitseva G. I. 2006. Pottery-making revolution in Northern Eurasia. In Man and Environment in Pleistocene and Holocene: Evolution of Waterways and Early Settlement of Northern Europe. St. Petersburg: 20. 
Oshibkina S. V. 1996. Ponjatie o neolite. Neolit Severnoy Evrazii. Izdatelstvo Nauka. Moskva: 6-9. (in Russian)

Özdoğan M. 2011. Archaeological evidence on the westward expansion of farming communities from Eastern Anatolia to the Aegean and the Balkans. Current Anthropology 52(4): 415-430.

Vasiliev I. B. 1981. Eneolit Povolzhya. Izdatelstvo Kuybyshevskogo pedagogichesrogo instituta. Kuybyshev. (in Russian)

2003. Hvalynskaya eneoliticheskaya kultura Volgo-Uralskoy stepi i lesostepi. In I. B. Vasiliev, Voprosy arheologii Povolzhya. Samara: 61-99. (in Russian)

Vybornov A. A. 2008. Neolit Volgo-Kamya. Izdatelstvo Samarskogo gosudarstvennogo pedagogicheskogo universiteta. Samara. (in Russian)

Vybornov A., Vasilyeva I. 2013. Interdisciplinary research of the Neolithic Volga-Kama pottery. Documenta Praehistorica 40: 165-173.

Vybornov A., Vasiliev I. and Komarov A. 2015. The Mesolithic of the North Caspian Sea Area. Izdatelstvo Povolzhskoy socialno-gumanitarnoy akademii. Samara.
Vybornov A., Kosintsev P. and Kulkova M. 2015. The Origin of Farming in Lower Volga Region. Documenta Praehistorica 42: 67-75.

Vybornov A. A., Yudin A. I. 2015. Raskopki poseleniya Oroshaemoe v Aleksandrovo-Gayskom rayone Saratovskoy oblasti v 2014 godu. In A. I. Yudin (ed.), Archeologicheskoe nasledie Saratovskoy kraya. Saratov: 3-33. (in Russian)

Vybornov A. A., Yudin A. I., Vasileva I. N., Kosintsev P. A., Kulkova M. A., Goslar T. and Doga N. S. 2015. Novye materialy neolita Nizhnego Povolzhya. Izvestiya Samarskogo nauchnogo tsentra Rossiyskoy akademii nauk 17(3): 235-241. (in Russian)

Vybornov A. A., Yudin A. I., Vasileva I. N., Kosintsev P. A., Kulkova M. A., Goslar T., Doga N. S. and Popov A. S. 2016. Issledovanie poseleniya Oroshaemoe v Nizhnego Povolzhya. Izvestiya Samarskogo nauchnogo tsentra Rossiyskoy akademii nauk 18(3): 140-145. (in Russian)

Yudin A. I. 2004. Varfolomeevskaya stoyanka $i$ neolit stepnogo Povolzhya. Izdatelstvo Saratovskogo Universiteta. Saratov. (in Russian)

Zaitseva G., Skripkin V., Kovaliukh N., Possnert G., Dolukhanov P. and Vybornov A. 2009. Radiocarbon dating of neolithic pottery. Radiocarbon 51(2): 795-801. 